\title{
The use of advertising activities to meet earnings benchmarks: Evidence from monthly data
}

\author{
Daniel Cohen \\ Stern School of Business \\ New York University \\ 44 West 4th Street \\ New York, NY 10012 \\ (212) 998-0267 \\ dcohen@stern.nyu.edu

\section{Raj Mashruwala} \\ Olin School of Business \\ Washington University in St. Louis \\ Campus Box 1133 \\ One Brookings Drive \\ St. Louis, MO 63130-4899 \\ (314) 935-5924 \\ mashruwala@wustl.edu \\ Tzachi Zach \\ Olin School of Business \\ Washington University in St. Louis \\ Campus Box 1133 \\ One Brookings Drive \\ St. Louis, MO 63130-4899 \\ (314) $935-4528$ \\ zach@wustl.edu
}

August 2007

\footnotetext{
${ }^{*}$ We gratefully acknowledge the financial support of the Center for Research in Economics and Strategy at the Olin School of Business. We have benefited from the comments of Eli Bartov, Nick Dopuch, Richard Frankel, April Klein, Thomas Lys, Paul Zarowin, Jerry Zimmerman and workshop participants at Washington University in St. Louis.
} 


\title{
The use of advertising activities to meet earnings benchmarks: Evidence from monthly data
}

\begin{abstract}
Using a unique and comprehensive data set of monthly information on advertising spending in media outlets, we examine whether managers engage in real earnings management to meet quarterly financial reporting benchmarks. We extend prior literature by: (1) examining quarterly as opposed to annual earnings benchmarks and separating advertising from other expenses, which allows us to incorporate advertising's unique characteristics; (2) exploring the possibility that managers could either reduce or boost advertising to increase chances of meeting an earnings benchmark; (3) investigating the timing, within a fiscal quarter, of altered advertising spending; and (4) analyzing actual activities as opposed to inferring them from reported expenses, which could also be influenced by accrual choices. Our analysis suggests that managers reduce their advertising spending to achieve the financial reporting goals of avoiding losses, avoiding earnings decrease, and meeting analysts' forecasts. We find some evidence that advertising spending increases during the third month of a fiscal quarter. This increase is stronger for managers who have incentives to meet earnings benchmarks and whose firms have higher margins. We find no evidence of an increased tendency to alter advertising spending after the Sarbanes-Oxley Act.
\end{abstract}




\section{The use of advertising activities to meet earnings benchmarks: Evidence from monthly data}

\section{Introduction}

Extensive evidence shows that managers engage in earnings management activities (for reviews of the evidence, see Healy and Wahlen [1999], Kothari [2001], and Fields, Lys, and Vincent [2001]). The literature to date identifies two main strategies to manage reported earnings: (i) accounting method changes and accrual-based earnings management that do not affect cash flows and (ii) real actions taken by managers that affect cash flows. The early evidence on earnings management concentrates on accrualbased strategies. More recently, Graham, Harvey, and Rajgopal [2005], in a survey of top executives, report that $80 \%$ of respondents would decrease discretionary spending (such as research and development and advertising) to achieve financial reporting objectives. Consistent with the survey, large sample evidence suggests that managers engage in real earnings management to avoid reporting annual losses (Roychowdhury [2006]). These actions have implications for future firm performance (Gunny [2005]) and are viewed as substitutes to accrual-based strategies (Zang [2006]).

While top executives recognize the importance of altering advertising activities as a means to achieve certain financial reporting objectives, large-scale empirical evidence to support this assertion does not exist. The literature to date has focused on other real activities, such as research and development, asset sales, and overproduction. Studies have only included advertising expenses (when they were available) as part of aggregate discretionary expenses. Given the economic importance of this item in a firm's business strategy, we fill the void in the literature by analyzing it separately. 
In this paper, we address the following research questions: (i) do managers use advertising activities to meet certain earnings benchmarks? (ii) are there circumstances in which managers will increase (rather than decrease) advertising activities to meet these benchmarks?, and (iii) is there a specific time during a fiscal period in which altering advertising activities to achieve financial reporting goals is more likely to occur?

To answer these questions we employ a data set of monthly advertising activities, because these questions cannot be answered with data available on Compustat. Our study contributes to the literature on real earnings management by extending it along several dimensions. First, our high-frequency data on advertising enable us to focus on a specific item that is subject to managerial discretion in order to meet quarterly earnings benchmarks — the benchmarks that the extant literature on meeting financial reporting benchmarks has mostly investigated (DeGeorge, Patell, and Zeckhauser [1999], Brown and Caylor [2005]). Survey evidence in Graham, Harvey, and Rajgopal [2005] also confirms that managers care about quarterly performance and benchmark beating. But because information on advertising expenses in Compustat is only available on an annual basis, analyzing managerial decisions about advertising expenses to meet quarterly benchmarks was not possible until now.

In addition, prior studies generally aggregate the annual advertising expense together with other discretionary expenses such as research and development and maintenance, or as part of selling and general expenses. For example, Roychowdhury [2006] aggregates several items, such as R\&D, SG\&A, and advertising, into a single annual measure of discretionary expenses. Zang [2006] and Gunny [2005] separately analyze a finer set of annual variables that proxy for real earnings management, which 
include abnormal levels of R\&D, SG\&A, production costs, and gains from asset sales. McNichols [2003] discusses the importance of disaggregating empirical measures of accounting choices in the context of accrual-based earnings management. Focusing on a single item provides a more powerful setting for the analysis and allows the exploration of richer theories about managerial actions that may vary depending on the item subject to discretion.

Our second contribution is exploring the possibility that managers increase (and not decrease) their advertising activities to attain certain accounting benchmarks. Prior studies have assumed that reducing discretionary expenses (including advertising) directly maps into a contemporaneous increase in reported earnings. However, because reduced advertising can quickly lower revenues in some cases, it is not clear whether reducing advertising activities will always be beneficial to managers. The marketing literature suggests that there is a variation across firms and products in the lead-lag relation between advertising activities and sales (Assmus, Farley and Lehmann, 1984). That is, for some firms advertising activities may trigger an immediate response in sales, while for others, advertising will generate the desired impact after a longer period. This raises the possibility that in some cases managers may choose to increase advertising to increase sales and short-term earnings, rather than decrease advertising only to lower expenses. Thus, the relation between advertising and reported income may be ambiguous.

Our comprehensive monthly data also allow us to study the timing of managerial choices regarding real activities, which is the third contribution of our study. This aspect, too, could not be achieved with existing large-scale data available through Compustat. Altering real activities, such as advertising, involves a tradeoff between two time 
considerations. On the one hand, managers are interested in taking actions early in the fiscal period to ensure that their financial effects will be reflected by the time the fiscal period ends. In this way, the probability of achieving the desired financial reporting objective is increased. On the other hand, managers would like to postpone real actions as much as possible, to acquire more information about the firm's expected financial performance for the period and about the magnitude of action needed to meet certain benchmarks. This learning minimizes the negative consequences of altering real activities. By examining high-frequency data, we are able to identify the month in which real earnings management may take place.

Fourth, our data are extracted from direct observation of advertising activities in a wide range of media outlets. According to GAAP, these advertising activities are expensed as incurred. This enables us to directly examine managerial actions that have immediate financial statement consequences. In contrast, prior studies that examine real earnings management rely on income statement expenses. These expenses, however, could be affected by accrual choices. These studies implicitly assume a one-to-one correspondence between real actions and the observed accounting figures. However, this assumption may not necessarily hold, especially in samples of firms that have incentives to achieve certain financial reporting objectives. Thus, prior evidence is subject to the alternative explanation that accrual choices (for example, aggressive capitalizations) affect the level of expenses, rather than the real choices made by managers.

Summary of the results. We find strong evidence that firms reduce their advertising spending in order to meet all three types of financial reporting objectives we examine - avoiding reporting a loss, meeting earnings from the same quarter in the 
previous year, and meeting analysts' forecasts or beating them by one cent. Utilizing the distinctive features of our high-frequency data, we find weaker evidence that there is an increase in abnormal advertising activities in the third month of a fiscal quarter. However, this increase is not limited to "suspect" firms, i.e., firms that have just met the three financial reporting objectives. One exception is that we do find evidence of increased advertising activities to meet analysts' forecasts during the third month of the fiscal quarter.

We find some circumstances in which firms have incentives to increase advertising spending to avoid reporting a loss. Specifically, firms with higher net margins are associated with higher abnormal advertising spending in the third month of the fiscal quarter. On the other hand, younger firms that are expected to have a shorter lead-lag period between advertising and sales do not increase their advertising. In fact, we find that older suspect firms are associated with higher abnormal advertising spending.

The paper proceeds as follows. In section 2 we survey the literature on real earnings management and develop our hypotheses. In section 3 we describe our research design. Section 4 describes our data. In section 5 we report the results. Section 6 concludes.

\section{Hypotheses development}

\subsection{Literature overview}

Accounting researchers have contemplated that managers manage earnings by cutting discretionary expenses to achieve certain earnings benchmarks such as (1) avoiding negative earnings, (2) avoiding earnings decreases and (3) meeting or beating analysts' forecasts (e.g., Burgstahler and Dichev [1997], Roychowdhury [2006]). Studies 
have referred to such activities as "real" earnings management, which is different than accrual manipulations in that it generally has direct cash flow consequences. Graham, Harvey, and Rajgopal [2005, p. 32] find

strong evidence that managers take real economic actions to maintain accounting appearances. In particular, $80 \%$ of survey participants report that they would decrease discretionary spending on $R \& D$, advertising, and maintenance to meet an earnings target. More than half (55.3\%) state that they would delay starting a new project to meet an earnings target, even if such a delay entailed a small sacrifice in value....

In surveys conducted by Bruns and Merchant [1990] and Graham, Harvey, and Rajgopal [2005], financial executives indicate a greater willingness to manage earnings through real activities than through accruals. There are at least two reasons for this preference. First, accrual-based earnings management is more likely to draw auditor or regulatory scrutiny than real decisions, such as those related to product pricing, production, and expenditures on research and development or advertising. Second, relying on accrual manipulation alone is risky. The realized shortfall between unmanaged earnings and the desired threshold can exceed the amount by which it is possible to manipulate accruals after the end of the fiscal period. If reported income falls below the threshold and all accrual-based strategies to meet it are exhausted, managers are left with no options because real activities cannot be adjusted at or after the end of the fiscal reporting period.

Zang [2006] analyzes the tradeoffs between accrual manipulations and real earnings management. She suggests that decisions to manage earnings through "real" actions precede decisions to manage earnings through accruals. Her results show that real manipulation is positively correlated with the costs of accrual manipulation, and that 
accrual and real manipulations are negatively correlated. These findings lead her to conclude that managers treat the two strategies as substitutes.

Roychowdhury [2006] focuses on real activities manipulations, which he defines as management actions that deviate from normal business practices, undertaken with the primary objective to mislead certain stakeholders into believing that earnings benchmarks have been met in the normal course of operations. Focusing on the zero earnings threshold and examining annual data, he finds evidence consistent with firms trying to avoid reporting losses in three ways: (1) boosting sales through accelerating their timing and/or generating additional unsustainable sales through increased price discounts or more lenient credit terms; (2) overproducing and thereby allocating more overhead to inventory and less to cost of goods sold, which leads to lower cost of goods sold and increased operating margins; or (3) aggressively reducing aggregate discretionary expenses (defined as the sum of research and development, advertising, and SG\&A expenses) to improve margins. This is most likely to occur when such expenses do not generate immediate revenues and income.

In related research, Gunny [2005] examines the consequences of real earnings management and finds that real earnings management has a significant negative impact on future operating performance. Additionally, it appears that capital markets participants mostly recognize the future earnings implications of managers' myopic behaviors.

While the above papers have addressed important and relevant issues regarding the determinants and economic consequences of real earnings management activities, their analyses rely solely on annual data. In examining managerial incentives to meet or beat earnings thresholds, the extant literature emphasizes the importance of studying 
quarterly benchmarks, especially in recent years (DeGeorge, Patell, and Zeckhauser [1999]; Brown and Caylor [2005]; Graham, Harvey, and Rajgopal [2005]). In particular, Graham, Harvey, and Rajgopal [2005, p. 5] conclude that

CFOs believe that earnings, not cash flows, are the key metric considered by outsiders. The two most important earnings benchmarks are quarterly earnings for the same quarter last year and the analyst consensus estimate. Meeting or exceeding benchmarks is very important.

They also write (p. 21):

Several performance benchmarks have been proposed in the literature. . . such as previous years' or seasonally lagged quarterly earnings, loss avoidance, or analysts' consensus estimates. The survey evidence. . . indicates that all four metrics are important: (i) same quarter last year (85.1\% agree or strongly agree that this metric is important); (ii) analyst consensus estimate (73.5\%); (iii) reporting a profit (65.2\%); and (iv) previous quarter EPS (54.2\%).

One of our contributions is to examine real earnings management utilizing higherfrequency monthly data on advertising expenses. This allows us to examine the relation between quarterly incentives and managerial behavior.

\subsection{The advertising context}

While existing evidence in the literature seems consistent with managers altering their operating decisions to achieve short-term earnings goals, there are at least two limitations to such an interpretation. First, it is not clear which types of discretionary expenses are subject to change and in which direction. For example, Roychowdhury [2006] pools all discretionary expenses together, by adding research and development, advertising, and SG\&A expenses. However, the costs of manipulation of different activities may vary. For example, reducing (or increasing) advertising may differ from reducing $R \& D$ in terms of the feasibility of acting quickly to reduce capacity. Altering advertising is expected to be easier - and quicker to execute - than changing $R \& D$, 
because it does not require disposal of assets and/or laying off workers. Moreover, the implications on short-term earnings may differ by the type of activity, in terms of both direction and magnitude. We elaborate on this point in section 2.5. These scenarios cannot be empirically captured in studying aggregate measures of discretionary expenses. Therefore, we separately analyze advertising activities to capture the short-term implications on earnings and minimize the variation in manipulation costs across various expense items.

The second limitation to interpreting the existing evidence as supportive of real earnings management is that it is based on reported expenses in the income statement. An analysis of expenses assumes a one-to-one mapping between advertising activities and their recorded expenses in the income statement. This may not necessarily hold if managers apply aggressive capitalizations to their advertising activities. As a result, this evidence is also consistent with accrual manipulation. ${ }^{1}$ In contrast, we examine the actual advertising activities that are observed in the marketplace using a database that tracks firms' advertising at their source. According to GAAP, advertising activities have to be expensed as incurred, and therefore our database includes all media-related advertising that should have been expensed in the period in which they were aired or printed. (For a detailed description of the accounting treatment of advertising under GAAP, please see

\footnotetext{
${ }^{1}$ For example, America Online has restated its results of operations in 1995 and 1996 to undo the capitalization of direct-response advertising. The effect on income was about $\$ 385$ million. "The specific issue in the AOL case concerned an accounting rule adopted in 1995 that carved out a small exception from the rule that advertising and promotional costs must be expensed - that is, deducted from profits - when they are incurred. The exception, the SEC said, allowed the capitalization of direct-response advertising costs 'only when persuasive historical evidence exists that allows the entity to reliably predict future net revenues that will be obtained as a result of the advertising.' . . . America Online said it would restate its books to remove the $\$ 385$ million write-off and instead apportion those costs during the earlier periods when they were incurred. There was no explanation from the SEC or the company as to why the settlement came so long after the facts were known. But it appeared that the company had resisted a settlement and gave in only after it became clear that the SEC would bring a case anyway" ("AOL pays a fine to settle a charge that it inflated profits," The New York Times, May 16, 2000).
} 
appendix A). As a result, we comment on actual real activities and not on the reported expenses, which could be a manifestation in financial statements of both real activities and accrual manipulations.

The above discussion leads to our first hypothesis, which is stated in its null form:

H1: Firms that are suspected to have managed earnings to achieve earnings benchmarks do not have abnormal advertising expenses that are different from firms that are not suspected to have managed earnings.

\subsection{Timing of advertising activities}

By using high-frequency monthly advertising data, we are able to examine the timing of decisions to alter discretionary expenses. ${ }^{2}$ When managing earnings through real activities, firms face a tradeoff between the costs of deviating from an optimal predetermined strategy for their advertising and the benefits of achieving an earnings target. To minimize the deviation costs, managers must have as much information as possible about the difference between current firm performance and the desired earnings benchmark. We argue that this information is more complete toward the end of a fiscal period, when there is better knowledge about expected pre-managed periodic performance. By waiting for a later point in the period, managers obtain more information about how much they need to alter their real activities. However, since real actions require some lag time to execute from the time a decision is made, managers cannot wait too long, or taking real actions will not be possible. Alternatively, managers

${ }^{2}$ Zang [2006] argues that there is a pecking order in the tradeoff between earnings management through real activities versus through accrual decisions. Specifically, managers exhaust the options for real accrual management before resorting to earnings management through accruals. In contrast, in our analysis we study the timing of real activities, which may occur before any accrual decisions are made. 
will pick the real actions that require the least amount of lag time for execution. Advertising activities require relatively shorter lag time between the decision and execution time, compared to, for example, research and development. Therefore, by analyzing advertising data, we are able to examine an activity that allows managers enough time to learn about current performance, and still provides ample time to react before the end of the quarter.

It is important to pinpoint the time in the fiscal quarter in which real activities are altered. The alternative explanations for a general reduction (or boosting) of advertising expenses is that these changes are (1) a rational response by managers to (unobservable) changes in business conditions, and/or (2) a result of accrual management through endof-period capitalizations. Controlling for unobservable changes in business conditions is very difficult. Thus, if abnormal expenses are not a result of real earnings management, but rather a result of one or both of the alternative explanations, then we expect abnormal levels of advertising expenses to occur throughout the quarter, and not necessarily during the last month of the quarter. In that respect, our study enables us to distinguish more clearly between alternative explanations for results in prior literature, to the extent that these prior results are driven, at least partially, by advertising activities. This leads to our second hypothesis:

H2: Firms that are suspected to have managed earnings to achieve earnings benchmarks will have abnormal advertising expenses (either positive or negative) during the last month of the quarter.

\subsection{The fourth fiscal quarter}

The accounting profession has been following an integral approach for interim reporting as mandated in APB Opinion No. 28 (APB [1973]), SFAS No. 3 (FASB 
[1974]), and FASB Interpretation No. 18 (FASB [1977]). The underlying premise of this approach is that the fiscal year is the main reporting period, while the quarterly financial reports are integral parts of the annual reporting process. ${ }^{3}$ The standards underlying the integral approach require the reporting firms to estimate many of the annual operating expenses and then allocate these estimates to interim quarters. Managers can defer and accrue certain costs depending on their expectations about the operations of the business for the fiscal year as well as other reporting incentives. In contrast, quarterly sales revenues can be recognized on the same basis as for the entire fiscal year period.

The principles of the integral approach will result in less precise interim estimates of cost accruals and deferrals in the first three fiscal quarters as compared to the fourth quarter. These cost estimates provide managers an opportunity to exert greater control over non-fourth quarter reported accounting figures relative to the level of fourth quarter earnings. Costs and expenses are estimated to a greater extent throughout the interim quarters compared to fiscal year-end, and in the interim quarters they are not necessarily audited by the firm's independent auditors. In summary, it appears that the integral approach allows managers more discretion and estimation over inter-period costs than is available at the fiscal year-end, i.e., in the fourth quarter.

The implementation of the integral approach coupled with the fourth quarter audit process suggests that the fourth fiscal quarter is different from the first three quarters. In our specific context, if managers indeed engage in both real and accrual earnings

\footnotetext{
${ }^{3}$ APB No. 28, paragraph 9, states that "the Board concluded that each interim period should be viewed primarily as an integral part of an annual period." The integral approach was preferred over a discrete alternative approach for interim reporting, under which each of the four quarters is viewed as a separate reporting period. This implies that accruals and deferrals under a discrete approach reflect the same principles used for annual reports by applying the same expense recognition principles to both interim and annual reports. Such an approach will result in no special interim accruals or any deferrals.
} 
management activities, and do so sequentially (Zang [2006]), we expect that real activities will be reduced during the fourth quarter. However, if advertising activities represent an opportunity for real earnings management with a relatively short lag between decision and action, then managers may still resort to such activities in the fourth quarter. This is especially true because accrual management in the fourth quarter is more difficult as a result of increased auditor oversight. The above arguments lead us to our third hypothesis:

H3: Firms that are suspected to have managed earnings to achieve earnings benchmarks will have abnormal advertising expenses during the last quarter of the fiscal year.

\subsection{Advertising's implications for reported earnings}

As mentioned before, prior studies aggregated advertising expenses along with other items. Such aggregate analysis of discretionary expenses implicitly assumes that cutting any one type of expense leads to a similar increase in short-term earnings. Consider a manager who has the option of reducing either R\&D or advertising activities to achieve a benchmark. The effect on short-term earnings of altering advertising activities may be different than the effect of altering R\&D. Moreover, managers who are interested in increasing short-term earnings may choose to either decrease or increase advertising. A reduction in advertising leads to an immediate reduction in operating expenses, and thus an increase in reported earnings for the concurrent period. For example, Netflix's CFO said during the 2005 third-quarter conference call, "we plan to cap our marketing spending just like we did in Q3 and meet our earnings guidance" (emphasis added). ${ }^{4}$ On the other hand, such reduction may quickly translate into a

\footnotetext{
${ }^{4}$ See the full transcript at http://internet.seekingalpha.com/article/3995.
} 
decrease in sales, which will reduce reported income. Thus, if the time lag between the occurrence of advertising and the reaction in sales is relatively short, managers may want to boost advertising to increase sales and, as a result, reported earnings, if margins are expected to be positive. For example, Blockbuster significantly increased its customer acquisition and marketing activities toward the end of the fourth quarter of 2006 to achieve the milestone target of two million subscribers to its online offering. ${ }^{5}$

Whether managers will decrease or increase advertising activities to boost shortterm earnings depends on, among other things, the lag between advertising outlays and the response in sales. The marketing literature studies the relation between advertising and sales along two dimensions: (i) actual response of sales to advertising (advertising elasticity) and (ii) the lasting effect of advertising on future sales (the carryover effect). ${ }^{6}$ This literature proposes several characteristics of firms and products that drive elasticity and carryover, because different products have distinct information needs and differences in product-market characteristics. This is important since we would expect firms with high advertising elasticity to increase advertising activities to meet earnings targets, while firms with low advertising elasticities would be more likely to cut advertising activities to meet earnings targets. Similarly, firms with high (low) advertising carryover will be more likely to decrease (increase) advertising activities to meet earnings targets.

5 "Blockbuster began offering free in-store rentals to subscribers of online rival Netflix Inc. on Tuesday as it tries to take market share from Netflix and reach its year-end subscriber goal. Netflix subscribers can get one free rental at Blockbuster stores for each address label they bring in from their Netflix mailing envelopes. The offer to Netflix subscribers, which runs until December 21, comes after Blockbuster began allowing subscribers to its own online rental service to swap DVDs they received in the mail at Blockbuster stores. The program, called Total Access, highlights the main difference between the two competitive services: Blockbuster has stores where consumers can immediately satisfy a desire for a particular movie. Blockbuster forecasted that it will add about 500,000 subscribers in the current quarter, to reach its yearend goal of 2 million total subscribers" (FinancialWire, December 6, 2006).

${ }^{6}$ See Assmus, Farley, and Lehmann [1984] for a review of this literature. 
Differences can be observed across product categories based on the stage of market development. For instance, elasticities should be higher during the early growth phase of a product market, when a significant number of new customers are added as adopters, than during the maturity phase of the product life-cycle, when most customers already have substantial experience with the product (Parsons [1975], Arora [1979], Winer [1979], Parker and Gatignon [1996]). Also, there are diminishing returns to advertising in that the first exposure of an advertisement is the most influential for shortterm sales or share gains (Deighton, Henderson, and Neslin [1994], Jones [1995], McDonald [1971]). Again, based on this, we would expect higher elasticities in the early stages of a product life-cycle.

The empirical question is whether, on average, firms decrease or increase advertising activities to achieve certain earnings benchmarks. We use two variables to proxy for firms' different approaches to increase reported earnings. First, we argue that firms with higher net margins are more likely to increase sales through increased advertising activities, because any increase in sales will translate into an increase in earnings, over and above the increase in advertising expenses. Second, we use firms' age to proxy for the elasticity between advertising and sales. As argued in the marketing literature, younger firms will tend to have higher elasticity of advertising-to-sales than older firms. Therefore, any increase in advertising activities in younger firms will translate into larger increases in sales than in older firms. This leads us to our fourth hypothesis:

H4: Firms that are suspected to have managed earnings to achieve earnings benchmarks are expected to decrease (increase) advertising activities if the expected benefit from reducing expenses is higher (lower) than the benefit from reduction in short-term sales. 


\subsection{The Sarbanes-Oxley Act of 2002}

Recent research has focused on evaluating and understanding the economic consequences of the Sarbanes-Oxley Act (SOX), arguably "the most far-reaching reforms of American business practices since the time of Franklin D. Roosevelt." In particular, as Graham, Harvey, and Rajgopal [2005, p.36] state:

... the aftermath of accounting scandals at Enron and WorldCom and the certification requirements imposed by the Sarbanes-Oxley Act may have changed managers' preferences for the mix between taking accounting versus real actions to manage earnings.

Analyzing trends in earnings management practices in the pre- and post-SOX periods, Cohen, Dey, and Lys [2007] find that firms switched from accrual-based to real earnings management methods after the passage of SOX. They report that firms that just achieved important earnings benchmarks used fewer accruals and more real earnings management strategies after SOX when compared to similar firms before SOX. In a related study, Cohen, Dey, and Lys [2005] provide evidence that following the passage of SOX, managers became more risk-averse and decreased their investments as manifested in lower capital expenditures and R\&D expenses.

The apparent change in managerial behavior with respect to the alternative strategies employed to meet certain earnings benchmark after SOX motivates us to examine whether any such change can be observed in advertising decisions. In particular, we examine whether managers are more likely to alter advertising activities in the postSOX period. Thus, our fifth hypothesis is:

H5: Cutting advertising expenses to meet earnings benchmarks is more likely to occur after the passage of the Sarbanes-Oxley Act (SOX).

\footnotetext{
${ }^{7}$ Elizabeth Bumiller, "Bush Signs Bill Aimed at Fraud in Corporations," New York Times, July 31, 2002.
} 


\section{Research design}

In this section, we describe how we measure (i) the incentives to manage earnings and meet financial reporting benchmarks, and (ii) the abnormal advertising activity, which is the hypothesized real activity used by managers to achieve their financial reporting objectives.

\subsection{Suspect firms}

We take the standard approach in the literature to identify firms that have incentives to manage real activities to meet or beat important accounting thresholds. We label these firms "suspect" firms. We define firms that are suspected to have managed earnings as those that fall in the areas immediately right of zero, in the cross-sectional distribution of: (i) earnings before extraordinary items (SUSPECT), (ii) changes in earnings relative to the same quarter in the previous year (SUSPECT_Q4), and (iii) analysts' forecast errors, defined as actual earnings minus analysts' forecasts (MBE). The presumption is that in these areas of the cross-sectional distribution, there is a higher frequency of firms that have managed earnings, including firms that managed earnings through real activities (e.g., Burgstahler and Dichev [1997]). Focusing on these specific firms enables us to increase the power of our tests. We classify suspect firms as those (i) whose quarterly earnings before extraordinary items (scaled by total assets) are between 0 and $0.00125 ;^{8}$ (ii) whose seasonal quarterly change in earnings, compared to the same quarter in the previous year, is between 0 and 0.005 ; and (iii) who just met the consensus analysts' forecast by one cent.

\footnotetext{
${ }^{8}$ Since we use quarterly data we divide the top of the range defined in Roychowdhury [2006] of 0.005 by a scale of 4 .
} 
We emphasize that classifying firm-quarter observations into the "suspect" categories has its drawbacks. First, since this classification is based on ex-post realizations, we are likely to overlook some firms that managed earnings through varying their advertising activities but did not fall into the narrow range immediately to the right of the relevant yardstick. Second, the "suspect" range may contain firms whose premanaged earnings were well above the yardstick, leading them to create reserves for future periods by managing earnings in the opposite direction, i.e., downwards. This effect will tend to reduce the power of our tests, because firms that reduce and increase earnings are pooled together in the same "suspect" group.

\subsection{Modeling abnormal advertising activities}

To evaluate whether managers change advertising activities in response to accounting-based incentives to meet certain benchmarks, we employ a firm-specific timeseries model to isolate the abnormal portion of advertising expense. In this model, we use up to 60 months of advertising data. The model we employ follows Foster [1977], who models the time-series of quarterly earnings. The quarterly earnings expectation from the Foster model is:

$$
E\left(Q_{t}\right)=\theta_{1} * Q_{t-4}+\theta_{2} *\left(Q_{t-1}-Q_{t-5}\right)+\varepsilon_{t}
$$

where $Q_{t}$ is earnings in quarter $\mathrm{t}, \mathrm{Q}_{\mathrm{t}-4}$ is an autoregressive term, and $\left(Q_{t-1}-Q_{t-5}\right)$ is a drift term. The Foster model assumes that earnings follow a first-order autoregressive process in seasonal differences. We adapt the Foster model to estimate a model for the monthly series of advertising outlays, as follows:

$$
E\left(A D S_{t}\right)=\theta_{1} * A D S_{t-12}+\theta_{2} *\left(A D S_{t-1}-A D S_{t-13}\right)+\varepsilon_{t}
$$


where $A D S_{t}$ is the monthly advertising outlay scaled by the annual sales during the prior year.

\section{Data}

\subsection{Advertising data}

We obtain information about monthly advertising activities from a proprietary database constructed by a large media-tracking company. Our sample covers the years 2001-2005. The data are gathered by continuously monitoring multiple media channels and collecting information about ad appearances. The media channels covered include (i) television (cable and network), (ii) print (newspapers, local magazines, consumer magazines and business magazines), (iii) radio (local and national), and (iv) internet. ${ }^{9}$ The translation of media spots to monetary amounts is done by surveying media channels for their rates at various points during the quarter. The data set covers all media spending that appears in the tracked channels and is reported by the brand advertised. For example, the media spending by Johnson \& Johnson is reported separately by its brands, which include Band-Aid, Tylenol, Neutrogena, etc. We aggregate the advertising outlays of all brands that belong to a particular sample firm. We emphasize that these data cover only media spending and do not include other forms of advertising, such as promotional materials and direct-response advertising (e.g., catalogs sent directly to consumers).

\subsection{Sample selection}

Table 1 reports the steps we took to construct our sample. To make sure that we include only firms that have substantial advertising budgets, we collect information about

\footnotetext{
${ }^{9}$ See Appendix B for a detailed description of each media channel.
} 
actual advertising activities and media spending information for firms whose average annual advertising expense over our sample period (2001-2005) exceeds $\$ 100,000$. We perform this initial screen using the annual advertising expense figure in Compustat (data\#45). Of those firms (2,312), we identify 1,542 firms that are covered in our proprietary database.

The main data requirement is the ability to estimate abnormal advertising activities using the time-series model described in equation (2). This limits our sample to 1,122 firms covering 33,841 monthly observations. Next, we separately construct three samples based on the variable we use to proxy for financial reporting incentives. As described in Table 1, after requiring sufficient data on some of the control variables, our samples cover between 755 and 1,076 firms, and the number of monthly observations varies from 18,098 to 30,143 .

\subsection{Summary statistics}

Table 2 reports summary statistics for our sample firms. On average, our sample firms' revenues are $\$ 3.8$ billion, with a median of $\$ 438$ million. As indicated by the difference between the mean and median, the sample is quite skewed with respect to size. Similar patterns emerge in total assets (mean of $\$ 4.7$ billion and median of $\$ 435$ million) and market capitalization (mean of $\$ 5.7$ billion and median of $\$ 506$ million). The average book-to-market ratio of firms in our sample is 0.76 , with a median of 0.42 .

The average annual advertising expenses as reported in Compustat (data\#45) for our sample firms is about $\$ 100$ million, with a median of $\$ 9.1$ million. Advertising expenses constitute about $4 \%$ of annual sales. Media-related advertising outlays tracked by the proprietary database we use are $\$ 44.5$ million, on average, for the same set of firms. This suggests that media-related outlays constitute about half of advertising 
expenses reported in the financial statements. The reason for the difference is that, as noted earlier, our database tracks only advertising activities related to media spending. It does not include other forms of advertising such as promotional materials and directresponse advertising such as catalogs sent to consumers, which are included as part of the advertising expense in Compustat. The correlation between the annual advertising expenses reported in Compustat and the annual media-related advertising is 0.85 .

\section{Results}

\subsection{Abnormal advertising activities}

We first report the results of estimating the time-series model of monthly advertising outlays as described in equation (2). The purpose of this model is to isolate the abnormal (discretionary) portion of advertising outlays. One advantage of modeling advertising outlays as an auto-regressive process is that it does not require a full specification of all potential determinants of the dependent variable. Instead, it assumes that the effect of changes in these determinants is captured in the lagged values of the dependent variable (i.e., advertising outlays), which are used as explanatory variables. An important feature of our research design is that the high-frequency monthly data we employ in our analyses enable us to estimate a firm-specific auto-regressive time-series model. Under this approach, the residuals one obtains are less likely to contain measurement errors that are correlated with omitted variables, unlike the residuals obtained from industry-based cross-sectional models used in prior studies.

Table 3 reports the estimation results of equation (2). The table reports summary statistics of the model's coefficients $-\theta_{1}$ and $\theta_{2}-$ for all 1,076 firm-specific models. The average number of months used in each firm-specific model is about 30 . We observe that 
monthly advertising media spending has a strong relation to the media spending in the same month of the prior year. The average of $\theta_{1}$ is about 0.80 , and this coefficient is statistically significant in over $85 \%$ of the firm-specific models. There is also a movingaverage component $\left(\theta_{2}\right)$, whose coefficient is 0.26 and is significant in over half of the models.

\subsection{Testing the hypotheses}

To test our hypotheses of managers' altering advertising activities to attain their financial reporting objectives, we estimate variations of the following regression model:

$$
A B N_{-} A D S_{t}=\alpha+\beta_{1} * \text { INCENTIVE }+\beta_{2} * Y+\beta_{4} \text { INCENTIVE } * Y+\text { Controls }+\varepsilon_{t}
$$

In equation (4), the dependent variable, $A B N_{-} A D S_{t}$, is the residual obtained from firm-specific time-series models of monthly advertising spending described in the previous section. While this approach tries to minimize the measurement error in our dependent variable, as discussed in the previous section, it is certainly not free from such error. However, since this measurement error appears in our dependent variable, its only effect would be manifested in a lower $\mathrm{R}^{2}$. Clearly, this is not likely to bias the inferences we draw based on the reported results.

INCENTIVE is an indicator variable that is a function of one of three financial reporting benchmarks: (i) SUSPECT is equal to one if a firm's quarterly earnings before extraordinary items (scaled by total assets) are between 0 and 0.00125 (i.e., the bin just to the right of zero); (ii) SUSPECT_4Q is equal to one if a firm's quarterly change in earnings, compared to the same quarter in the previous year, is between 0 and 0.005 ; and (iii) $M B E$ is equal to one if a firm just met the consensus analysts' forecast by one cent; 
We interact the main incentive variables with several variables (Y's) that test our hypotheses $\mathrm{H} 2-\mathrm{H} 5$. For hypothesis 2 , we use an indicator variable (MONTH3) that is equal to one if the advertising spending occurred during the last month of a fiscal quarter. For hypothesis 3, we use an indicator variable (QTR4) that is equal to one if the advertising spending occurred during the fourth fiscal quarter. For hypothesis 4 , we use two continuous variables - the natural logarithm of firm's age (LNAGE) and the firm's net margin (MARGIN). For hypothesis 5, we use an indicator variable (SOX) that is equal to one if the advertising spending occurred after 2003.

Our control variables include SIZE - the market capitalization of the firm at the beginning of the fiscal year, INCOME - quarterly earning before extraordinary items deflated by beginning of the year's assets, and $B M-$ the book-to-market ratio at the beginning of the fiscal year.

Hypotheses 1-3. Tables 4-6 report the results of estimating several versions of equation (4). The tables vary depending on the financial reporting benchmark that is being tested. To account for potential dependence among the monthly observations, we calculate the standard errors after clustering observations at the firm level (Petersen [2005]). Thus, all our statistical tests are based on clustered standard errors.

Beginning with Table 4, where the financial reporting objective is to avoid reporting a loss (proxied by the SUSPECT variable), we find that in all specifications, the coefficient on SUSPECT is negative and highly significant (p-values of less than 0.01 ). This result is consistent with $\mathrm{H} 1$, which suggests that firms manage their advertising activities to report earnings that just meet the zero earnings benchmark. Moreover, the negative sign indicates that, on average, suspect firms choose to reduce advertising 
activities. Recall that in the case of advertising spending, it is possible that firms would boost advertising activities in order to increase sales and earnings. However, our results indicate that, on average, this does not occur. The negative sign on SUSPECT is consistent with the findings in Roychowdhury [2006], who examines an aggregate variable of annual discretionary expenses that include research and development, general and administrative, and advertising expenses.

A few points are worth mentioning. First, our results pertain to actual real activities taken by managers. This is possible due to the unique feature of our data that enables us to observe the actual ads that, according to GAAP, are supposed to be expensed as incurred. Past studies have employed expense-based measures of real activities, which are also subject to accrual manipulation (for example, aggressive capitalizations). Therefore, past results could be attributed to both real earnings management and accrual manipulations. Our advertising spending measures are not affected by accrual considerations and therefore can be directly attributed to real activities. Second, we utilize quarterly financial reporting benchmarks that, as reported in Graham, Harvey, and Rajgopal [2005] and Brown and Caylor [2005], are perceived by managers to be more important than the annual benchmark used in Roychowdhury [2006]. Third, none of the studies in the literature (Gunny [2005], Roychowdhury [2006], Zang [2006]) has separately examined advertising activities. As such, our study provides a finer measure of a single activity as opposed to a coarser measure of multiple activities. Finally, our high-frequency data provide us with an opportunity for the most powerful setting for testing our hypotheses. 
In addition to reporting the statistical significance of the results, we are also able to assess the economic significance of the findings pertaining to the SUSPECT variable. Specifically, the coefficient on SUSPECT indicates that suspect firms reduce their monthly advertising spending by $0.04 \%$ of annual sales, or the quarterly advertising spending by $0.12 \%$ of annual sales. The average annual sales in our sample is $\$ 3.8$ billion. This means that suspect firms reduce their quarterly advertising outlays by $\$ 4.6$ million. This reduction constitutes, on average, about $41.5 \%$ of quarterly media-related advertising expenses.

Specification (3) in Table 4 reports the results when we add the MONTH3 variable and the interaction term SUSPECT*MONTH3. The coefficient on MONTH3 is positive and significant. This means that, on average, firms increase their advertising outlays in the last month of the fiscal quarter. Examining the interaction term SUSPECT*MONTH3 sheds light on our second hypothesis. The coefficient on SUSPECT*MONTH3 is not significant. Thus, we do not find evidence that suspect firms are more likely to reduce their advertising activities in the third month of a fiscal quarter. This non-significant result can be interpreted in two alternative ways.

First, it is possible that the lag between the decision to cut spending and the actual reduction in spending is not short enough to enable firms to adjust their advertising spending in the last month of a fiscal quarter. Recall that firms would like to postpone cutting spending to a time when information about expected quarterly performance is more accurate. Thus, any decision to cut advertising activities to meet earning benchmarks occurs before the third month of the fiscal quarter. This is also consistent 
with Zang [2006], who argues that decisions about real activities occur earlier in the fiscal period, and before any accrual manipulations.

The second interpretation assumes that altering of real activities can only occur late in the quarter because managers need to learn about the firm's ongoing performance in order to know how much to alter real activities. This assumption, of course, is feasible only in activities that are quick to alter, such as advertising. Under this assumption, the reduction in quarterly advertising activities is not a response to accounting incentives to meet certain benchmarks, but rather a reaction to some unobserved changes in economic conditions. One advantage of our high-frequency setting is that it provides us an opportunity to explore this alternative interpretation in a powerful way with monthly data. We believe that our setting is powerful enough to find an effect in the third month, for two reasons. First, unlike previous studies that pool together several types of discretionary operating expenses, our focus on a single item increases the likelihood that our model is well specified. Second, our use of a long firm-specific time-series of advertising spending further enhances our confidence in the model, which attempts to separate normal and abnormal advertising activities.

The rightmost column in Table 4 reports the results of estimating equation (4) including the indicator variable QTR4, which equals to one if the observation's fiscal quarter is the fourth quarter. In addition, we include the interaction term SUSPECT*QTR4 to examine whether the general effect of SUSPECT is different during the fourth quarter. The coefficients on both of these variables are insignificant. This suggests that the general effect of suspect firms to reduce advertising spending is not different in the fourth quarter. This result is consistent with firms not using incremental 
manipulation of real activities in the fourth quarter because of their lack of ability to alter these actions late in the fiscal year (Zang [2006]). However, since we believe that advertising spending is among the real activities with the shortest lag between decision and execution, our interpretation suggests that the documented reductions, which do not vary by incentives, may not be due to manipulations of real activities. ${ }^{10}$

Finally, the only control variable to load significantly is SIZE. Its negative sign suggests that larger firms are more likely to have lower abnormal advertising activities. The sign on market capitalization is different than that reported in prior studies (e.g., Roychowdhury [2006]. Note, however, that the dependent variable is also different because it only captures a subset of the expenses measured in Roychowdhury [2006].

Table 5 reports the estimation results of similar models to those reported in Table 4. The difference is that the incentive variable, SUSPECT_4Q, is defined based on the changes in earnings before extraordinary items relative to the same quarter in the previous year. The results in Table 5 are similar to those reported in Table 4. First, the coefficient on SUSPECT_4Q is consistently negative and significant. Second, there is weak evidence of higher abnormal advertising spending during the third month of the fiscal quarter, as the coefficient of MONTH3 is marginally significant (p-value of 0.09 ). There is no evidence of incremental abnormal advertising spending by suspect firms during the third month of the fiscal quarter, as the coefficient on the interaction term

\footnotetext{
${ }^{10}$ In untabulated results, we assess the impact of changes in real economic conditions on altering discretionary advertising spending by including the percentage change in seasonally adjusted Gross Domestic Products over the previous quarter in our regression models, as an additional explanatory variable. This variable is insignificant, and the variable SUSPECT remains negative and strongly significant. This leads us to conclude that the variable SUSPECT does not merely capture response to changes in economic conditions, at least as they are captured by changes in GDP.
} 
SUSPECT_4Q*MONTH3 is not significantly different from zero. In addition, we do not find evidence of abnormal advertising spending in the fourth fiscal quarter.

In Table 6, we report results of the third proxy for meeting financial reporting goals, $M B E$, which uses analysts' forecasts as the benchmark. $M B E$ is an indicator variable that takes the value of one if the firm's earnings per share for the quarter met the last outstanding analyst consensus forecast by one cent per share or less. Notice, first, that the number of observations declines to about 18,000 , and the number of firms decreases to about 760 . This reduction is due to additional data requirements imposed by IBES coverage. The coefficient on the main incentive variable, MBE, is negative in most specifications, similar to the previous tables. However, the statistical significance of the evidence is slightly weaker. This could be due to the fact that when trying to meet analysts' forecasts, managers do not know exactly what the target should be, as analysts keep updating their quarterly forecasts throughout the fiscal period. In other words, the benchmark that managers try to beat is a moving target, and is perhaps harder to achieve through the manipulation of advertising spending.

As for QTR4, we find that abnormal advertising spending is higher in the fourth quarter (p-value of 0.009 on QTR4). We also find that the entire significant effect of meeting analysts' forecasts through advertising spending is attributed to the fourth fiscal quarter. Notice that $M B E$ turns insignificant while the interaction term $M B E^{*} Q T R 4$ is highly significant. This suggests that with respect to analysts' forecasts, managers are able to reduce advertising spending only for the final quarter of the year. This could be consistent with managers learning throughout the year and, thus, having better 
information about analysts' fourth-quarter forecasts as well as about the firm's actual annual financial performance.

Hypothesis 4. Recall that in our fourth hypothesis we raised the possibility that managers may either decrease or increase advertising activities to achieve certain earnings benchmarks. This depends on the length of the lead-lag relationship between advertising activities and their sales response. It also depends on firms' net margins. In Table 7, we use two different variables to test this hypothesis. In the first column, we include the natural log of firms' age to proxy for the elasticity between advertising and sales. It is argued that younger firms will tend to have a higher elasticity of advertisingto-sales than older firms. Therefore, any increase in advertising activities in younger firms will translate into larger increases in sales than in older firms. We find that older firms tend to have lower abnormal advertising spending, as reflected in the negative coefficient on LNAGE. Our main interest lies in the interaction term SUSPECT*LNAGE. Its coefficient is positive $(0.0004)$ and highly significant. This suggests that older suspect firms (and not younger) tend to increase advertising activities to avoid reporting losses. We do not find evidence that such an increase occurs in the third month of the fiscal period. This result is contrary to the expectation that younger firms will tend to increase advertising because of the higher elasticity of their advertising activities.

The second column in Table 7 examines the association of net margin with the change in advertising activities. Firms with higher net margins are more likely to increase sales through increased advertising activities, because any increase in sales will translate into an increase in earnings, over and above the increase in advertising expenses. We find no evidence that the general trend suggests an increase in advertising activities for 
suspect firms with higher net margins (SUSPECT*MARGIN is insignificant). However, we find evidence that suspect firms with high margins increase their advertising activities in the third month of the fiscal quarter. The coefficient on the interaction term SUSPECT*MARGIN*MONTH3 is positive (0.0258) and significant (p-value of 0.023). In untabulated results we include both age and margin. The results are similar to those reported for the separate models.

Hypothesis 5. In our final hypothesis we examine whether there is an increase in the tendency of managers to engage in real earnings management in the form of altering advertising activities to meet certain benchmarks following the Sarbanes-Oxley Act. According to Graham, Harvey, and Rajgopal [2005], managers' preferences for using real- versus accrual-based strategies may have changed after the new legislation. Table 8 reports results of our basic model, including an indicator variable, SOX, that equals to one in the years 2003-2005. The coefficient on SUSPECT*SOX is insignificant. Thus, we find no evidence of an increased likelihood of using advertising activities to avoid reporting losses in the post-SOX period.

\section{Conclusion}

In this paper we study whether managers alter their advertising spending to achieve financial reporting objectives, such as avoiding reporting a loss, avoiding reporting a decrease in earnings, and meeting analysts' consensus forecasts. We do so by utilizing a unique and comprehensive data set of monthly advertising spending in media outlets. This data set enables us to directly analyze actual real managerial activities that, according to GAAP, should be expensed as incurred. This is in contrast to examining reported expenses, which are also subject to accrual manipulations. Therefore, our 
approach is different than the one used in prior studies in which reported expenses serve as an indirect proxy for inferring real earnings management. Our data on advertising activities also allow us to focus on a specific item that is subject to managerial discretion as opposed to an aggregate proxy of several discretionary expenses activities. Finally, the high-frequency feature of our data set provides us with a powerful setting to investigate the incentives to meet quarterly earnings benchmarks as well as to examine the timing of real activities' manipulations.

We find strong evidence that firms reduce their advertising spending in order to meet all three types of financial reporting objectives we examine. We find weaker evidence of an increase in abnormal advertising activities in the third month of a fiscal quarter. However, this increase is not limited to "suspect" firms, i.e., firms that have just achieved the three financial reporting objectives. One exception is that we do find evidence of increased advertising activities to meet analysts' forecasts during the third month of the fiscal quarter. Finally, we uncover circumstances in which firms have incentives to increase advertising spending to avoid reporting a loss. Specifically, firms with higher net margins are associated with higher abnormal advertising spending in the third month of the fiscal quarter.

Overall, this study contributes to the emerging literature on real earnings management activities. The evidence we provide enhances our understanding of the interplay between managers' incentives and the real actions managers take to achieve financial reporting goals. 


\section{References}

Accounting Principles Board. Interim Financial Reporting. APB Opinion No. 28. New York, 1973.

Arora, R. "How Promotion Elasticities Change." Journal of Advertising Research 19(3) (1979): 57-62.

Assmus, G.; J. Farley; and D. R. Lehmann. "How Advertising Affects Sales: Metaanalysis of Econometric Results." Journal of Marketing Research, 21(1) (1984): 6574.

Brown, L., and M. Caylor. "A Temporal Analysis of Quarterly Earnings Thresholds: Propensities and Valuation Consequences." The Accounting Review 80(2) (2005): $423-40$.

Bruns, W., and K. Merchant. "The Dangerous Morality of Managing Earnings." Management Accounting 72(2) (1990): 22-5.

Burgstahler, D., and I. Dichev. "Earnings Management to Avoid Earnings Decreases and Losses." Journal of Accounting and Economics 24(1) (1997): 99-126.

Cohen, D.; A. Dey; and T. Lys. "The Sarbanes Oxley Act of 2002: Implications for Compensation Structure and Risk-taking Incentives of CEOs." Working paper, New York University, 2005.

Cohen, D.; A. Dey; and T. Lys. "Real and Accrual Based Earnings Management in the Pre and Post Sarbanes Oxley Periods." Working paper, New York University, 2007.

DeGeorge, F.; J. Patell; and R. Zeckhauser. "Earnings Management to Exceed Thresholds." Journal of Business 72 (1979): 1-33.

Deighton, J.; C. Henderson; and S. Neslin. "The Effects of Advertising on Brand Switching and Repeat Purchasing." Journal of Marketing Research 31(1) (1994): 2843.

Fields, T. D.; T. Z. Lys; and L. Vincent. "Empirical Research on Accounting Choice." Journal of Accounting and Economics 31 (2001): 255-307.

Financial Accounting Standards Board (FASB). Reporting Accounting Changes in Interim Financial Statements. Statement of Financial Accounting Standards No. 3. Stamford, CT, 1974.

Financial Accounting Standards Board (FASB). FASB Interpretation No. 18. Accounting for Income Taxes in Interim Periods. Stamford, CT, 1977.

Foster, G. "Quarterly Accounting Data: Time-Series Properties and Predictive Ability Results." The Accounting Review 52 (1977): 1-21. 
Graham, J. R.; C. R. Harvey; and S. Rajgopal. "The Economic Implications of Corporate Financial Reporting." Journal of Accounting and Economics 40 (2005): 3-73.

Gunny, K. "What Are the Consequences of Real Earnings Management?" Working paper, University of Colorado, 2005.

Healy, P., and J. Wahlen. "A Review of the Earnings Management Literature and Its Implications for Standard Setting." Accounting Horizons 13 (1999): 365-84.

Jones, J. “Exposure Effects Under a Microscope.” Admap, 30 (February) (1995): 28-31.

Kothari, S. P. "Capital Market Research in Accounting." Journal of Accounting and Economics 31 (2001): 105-231.

McDonald, C. "What Is the Short Term Effect of Advertising?" In Measuring the Effect of Advertising, D. Corkindale and S. Kennedy, eds. Farnborough, England: Saxon House Studies, 1971: 463-87.

McNichols, M. Discussion of "Why Are Earnings Kinky? An Examination of the Earnings Management Explanation." Review of Accounting Studies 8 (2003), 385-91.

Parker, P. M., and H. Gatignon. "Order of Entry, Trial Diffusion, and Elasticity Dynamics: An Empirical Case." Marketing Letters 7(1) (1996): 95-109.

Parsons, L. "The Product Life Cycle and Time-Varying Advertising Elasticities." Journal of Marketing Research 12 (November) (1975): 476-80.

Petersen, M. "Estimating Standard Errors in Finance Panel Data Sets: Comparing Approaches." Working paper, Northwestern University, 2005.

Rogers, W. "Regression Standard Errors in Clustered Samples." Stata Technical Bulletin 13 (1993):19-23.

Roychowdhury, S. "Earnings Management through Real Activities Manipulation." Journal of Accounting and Economics 42 (2006): 335-70.

Winer, R. S. "An Analysis of the Time-Varying Effects of Advertising: The Case of Lydia Pinkham." Journal of Business 52(4) (1979): 563-76.

Zang, A. "Evidence on the Tradeoff between Real Manipulation and Accrual Manipulation." Working paper, University of Rochester, 2006. 


\section{Appendix A}

Our database records advertising activities at the time they appear in a media outlet (e.g., when they are aired on television or appear in print). According to Statement of Position (SOP) 93-7: Reporting on Advertising Costs, firms are required to expense advertising activities as they are incurred. Thus, if firms follow GAAP, our database will include all media-related advertising that should have been expensed in the period in which they were aired or printed.

The following paragraphs from SOP 93-7 describe the accounting treatment in detail:

\section{Paragraph 26}

The costs of advertising should be expensed either as incurred or the first time the advertising takes place... except for--

a. $\quad$ Direct-response advertising (1) whose primary purpose is to elicit sales to customers who could be shown to have responded specifically to the advertising and (2) that results in probable future economic benefits.

b. Expenditures for advertising costs that are made subsequent to recognizing revenues related to those costs

\section{Paragraph 42}

Advertising activities may have several component costs. Two primary components, which are made up of other components, are the costs of (a) producing advertisements, such as the costs of idea development, writing advertising copy, artwork, printing, audio and video crews, actors, and other costs, and (b) communicating advertisements that have been produced, such as the costs of magazine space, television airtime, billboard space, and distribution (postage stamps, for example).

\section{Paragraph 43}

Costs of producing advertising are incurred during production rather than when the advertising takes place.

\section{Paragraph 44}

Costs of communicating advertising are not incurred until the item or service has been received and should not be reported as expenses before the item or service has been received... For example--

- The costs of television airtime should not be reported as advertising expense before the airtime is used. Once it is used, the costs should be expensed, unless the airtime was used for direct-response advertising activities that meet the criteria for capitalization under this SOP.

- The costs of magazine, directory, or other print media advertising space should not be reported as advertising expense before the space is used. Once it is used, 
the costs should be expensed, unless the space was used for direct-response advertising activities that meet the criteria for capitalization under this SOP.

Our database contains only media-related advertising that cannot be treated as directresponse advertising and therefore has to be expensed in the period of appearance.

Suppose that an advertisement appeared on television on January 15, 2007. This advertisement will be captured in our database. If the firm follows GAAP, the advertisement will appear as an expense in the financial statements for the quarter ending on March 31, 2007. Thus, our database captures all media-related advertising activities during the period that are supposed to be expensed in the income statement. 


\section{Appendix B}

This appendix describes the various media outlets from which the advertising data are collected.

1. Television

Cable Television: Commercial occurrences and advertising activities information for 52 cable television networks. Cable television is monitored via satellite 24 hours a day, 365 days a year.

Spot Television: Commercial occurrence and expenditure information for more than 600 English-speaking stations and 35 Spanish-speaking stations in 100 major markets. Spot television is monitored 21 hours a day $(5$ a.m. to 2 a.m.). The monitored stations constitute the principal stations in each market and typically include the network affiliates, major independents, and Spanish affiliates. Public broadcasting stations are not monitored.

Network Television: Commercial occurrence and expenditure information for seven broadcast networks: ABC, CBS, FOX, NBC, PAX/I, MNTV, and CW.

2. Print

Magazines: All paid advertising space and expenditure data in over 350 consumer magazines and over 30 local magazines.

Newspapers: All advertising space in over 250 daily and Sunday newspaper editions and Sunday magazines, including national newspapers such as The New York Times, USA Today, and Wall Street Journal. In national newspapers, all national and regional editions are measured.

3. Radio

Local Radio: Data are based on the tracking of radio billings by stations in more than 100 radio markets.

National Spot Radio: Nationally placed spot radio data for approximately 4,000 stations in more than 225 markets. Reported expenditures are based on audited billings from contract information provided by the following major national station representative organizations: ABC, Allied, Christal, Clear Channel, Cumulus, D\&R, Infinity, Katz, KHM, Lotus, and McGavren.

4. Internet

Advertising expenditure information is measured for over 2,500 sites and 90,000 brands in the United States and Canada. A proprietary spider probes the sites on an ongoing basis and captures and stores every image on a page. 
Table 1. Sample construction. This table describes the sample construction procedure. Each of our three samples is based on the same information on monthly advertising activities. The monthly advertising outlays are drawn from a proprietary database and are for the period 2001-2005. The samples differ on the type of financial reporting benchmark hypothesized to affect managers' incentives to alter their advertising activities.

\section{Number Number of \\ of firms monthly \\ observations}

Firms with material advertising expense

2,312

Firms covered in the proprietary database

1,542

Firms and observations with sufficient information to

1,122

33,841

compute abnormal advertising measures

\section{Sample 1}

Observations with sufficient information to calculate $\quad 1,122 \quad 33,013$

the SUSPECT variable, based on quarterly income

Observations with sufficient information to calculate

1,076

30,143

SIZE, INCOME, and BM

\section{Sample 2}

Observations with sufficient information to calculate

1,026

29,598

the SUSPECT_4Q variable, based on change in income relative to the same quarter in the prior year

Observations with sufficient information to calculate

986

27,696

SIZE, INCOME, and BM

\section{Sample 3}

Observations with sufficient information to calculate

the MBE variable, based on analysts' forecast errors

Observations with sufficient information to calculate 
Table 2. Descriptive statistics for sample firms. This table reports summary statistics for our final sample of 1,076 firms. The numbers reported are the summary of the firmaverage across the five sample years. Sales is defined as the annual figure of total sales in million of dollars from Compustat (data\#12). Assets is defined as total assets from Compustat (data\#6). BM is the book-to-market ratio. Advertising expenses is the annual advertising expense from Compustat (data\#45). Advertising outlays is the annual sum of all monthly media-related advertising outlays tracked by our proprietary database.

\begin{tabular}{lccccc} 
& Mean & Median & Std & $\mathbf{2 5 \%}$ & $\mathbf{7 5 \%}$ \\
\hline Sales (Mil \$) & 3,848 & 438.3 & 14,569 & 118.3 & $1,654.1$ \\
Assets (Mil \$) & 4,743 & 435.2 & 21,314 & 122.4 & 1,699 \\
Market capitalization (Mil \$) & 5,695 & 506.2 & 22,902 & 136.0 & $2,034.3$ \\
BM & 0.76 & 0.42 & 4.01 & 0.24 & 0.70 \\
Advertising expenses (Mil \$) & 100.2 & 9.1 & 360.6 & 1.7 & 42.2 \\
Ad expenses/Sales & $4.03 \%$ & $1.94 \%$ & $8.06 \%$ & $0.88 \%$ & $4.61 \%$ \\
Advertising outlays (Mil \$) & 44.5 & 1.76 & 187.3 & 0.25 & 13.1 \\
Ad outlays/Sales & $2.35 \%$ & $0.49 \%$ & $8.95 \%$ & $0.11 \%$ & $1.81 \%$ \\
\hline
\end{tabular}


Table 3. Results of time-series models of monthly advertising expenditures. This table reports summary statistics of coefficients from estimating a firm-specific time-series model of monthly advertising expenditures. The average (median) number of observations per firm is 30.5 (17.4). The model is an adaptation of the Foster [1977] model for quarterly earnings:

\begin{tabular}{lcc}
\multicolumn{3}{c}{$E\left(A D S_{t}\right)=\theta_{1} * A D S_{t-12}+\theta_{2} *\left(A D S_{t-1}-A D S_{t-13}\right)+\varepsilon_{t}$} \\
& $\boldsymbol{\Theta}_{1}$ & $\boldsymbol{\Theta}_{2}$ \\
\hline $\mathrm{N}$ & 1,077 & 1,077 \\
Mean & 0.7932 & 0.2640 \\
Standard deviation & 0.6071 & 0.3154 \\
& & \\
$10 \%$ & 0.2753 & -0.0900 \\
$25 \%$ & 0.5692 & 0.0254 \\
Median & 0.7999 & 0.2563 \\
$75 \%$ & 0.9488 & 0.4849 \\
$90 \%$ & 1.047 & 0.6568 \\
\hline$\%$ significant (5\%) & 86.8 & 51.2 \\
\hline
\end{tabular}


Table 4. Tests of real earnings management based on monthly advertising activities. The table reports estimation results of models whose dependent variable is monthly abnormal advertising expenditures. These are calculated based on the residuals from firm-specific time-series models estimated up to 60 months (an average of 30 months). SUSPECT is an indicator variable equal to one if quarterly income before extraordinary items deflated by total assets is above 0 and less than $0.0125 \%$. MONTH3 is an indicator variable equal to one if the month is the third month of a fiscal quarter. QTR4 is an indicator variable equal to one if the quarter is the fourth fiscal quarter. INCOME is income before extraordinary items deflated by total assets at the beginning of the year; $\mathrm{BM}$ is the book-to-market ratio. SIZE is the natural logarithm of market capitalization. Pvalues in parentheses are based on robust firm-clustered standard errors (e.g., Rogers [1993], Petersen [2005]). ***,**, and * indicate significance at $1 \%, 5 \%$, and $10 \%$ levels.

(1)

INTERCEPT

SUSPECT

MONTH3

SUSPECT*MONTH3

QTR4

SUSPECT*QTR4

SIZE

INCOME

BM

Observations

Adjusted R-squared

(2)

0.0004

$(0.000)^{* * *}$

$-0.0003$

$(0.000)^{* * *}$

-0.0004
$(0.001)^{* * *}$

0.0014

$(0.001)^{* * *}$

(n)

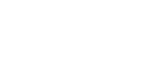

(3)

(4)

4) . 
Table 5. Tests of real earnings management based on monthly advertising expenditures. The table reports estimation results of models whose dependent variable is monthly abnormal advertising expenditures. These are calculated based on the residuals from firm-specific time-series models estimated up to 60 months (an average of 30 months). SUSPECT_4Q is an indicator variable equal to one if the changes in quarterly income before extraordinary items deflated by total assets is above 0 and less than $0.05 \%$. MONTH3 is an indicator variable equal to one if the month is the third month of a fiscal quarter. QTR4 is an indicator variable equal to one if the quarter is the fourth fiscal quarter. INCOME is income before extraordinary items deflated by assets at the beginning of the year; BM is the book-to-market ratio. SIZE is the natural logarithm of market capitalization. P-values in parentheses are based on robust firm-clustered standard errors (e.g., Rogers [1993], Petersen [2005]). ***, **, and * signify significance at $1 \%$, $5 \%$, and $10 \%$ levels.

\section{(1)}

(2)

(3)

(4)

\begin{tabular}{|c|c|c|c|c|}
\hline INTERCEPT & $\begin{array}{c}0.0005 \\
(0.000)^{* * *}\end{array}$ & $\begin{array}{c}0.0020 \\
(0.001)^{* * *}\end{array}$ & $\begin{array}{c}0.0020 \\
(0.001)^{* * *}\end{array}$ & $\begin{array}{c}0.0020 \\
(0.001)^{* * *}\end{array}$ \\
\hline SUSPECT_4Q & $\begin{array}{c}-0.0004 \\
(0.000)^{* * *}\end{array}$ & $\begin{array}{c}-0.0003 \\
(0.000)^{* * *}\end{array}$ & $\begin{array}{c}-0.0002 \\
(0.001)^{* * *}\end{array}$ & $\begin{array}{c}-0.0003 \\
(0.000)^{* * *}\end{array}$ \\
\hline MONTH3 & & & $\begin{array}{c}0.0001 \\
(0.090)^{*}\end{array}$ & \\
\hline SUSPECT_4Q*MONTH3 & & & $\begin{array}{r}-0.0001 \\
(0.410)\end{array}$ & \\
\hline QTR4 & & & & $\begin{array}{l}0.0000 \\
(0.900)\end{array}$ \\
\hline SUSPECT_4Q*QTR4 & & & & $\begin{array}{c}0.0000 \\
(0.778)\end{array}$ \\
\hline SIZE & & $\begin{array}{c}-0.0002 \\
(0.008)^{* * *}\end{array}$ & $\begin{array}{c}-0.0002 \\
(0.008)^{* * *}\end{array}$ & $\begin{array}{c}-0.0002 \\
(0.008)^{* * *}\end{array}$ \\
\hline INCOME & & $\begin{array}{c}-0.0080 \\
(0.104)\end{array}$ & $\begin{array}{c}-0.0080 \\
(0.104)\end{array}$ & $\begin{array}{c}-0.0080 \\
(0.104)\end{array}$ \\
\hline BM & & $\begin{array}{c}-0.0005 \\
(0.012)^{* *}\end{array}$ & $\begin{array}{c}-0.0005 \\
(0.012)^{* *}\end{array}$ & $\begin{array}{c}-0.0005 \\
(0.012)^{* *}\end{array}$ \\
\hline Observations & 29,598 & 27,696 & 27,696 & 27,696 \\
\hline Adjusted R-squared & 0.0005 & 0.0066 & 0.0066 & 0.0066 \\
\hline
\end{tabular}


Table 6. Tests of real earnings management based on monthly advertising activities. The table reports estimation results of models whose dependent variable is monthly abnormal advertising expenditures. These are calculated based on the residuals from firm-specific time-series models estimated up to 60 months (an average of 30 months). MBE is an indicator variable that takes the value of one if the firm's earnings per share for the quarter met the last outstanding analyst consensus forecast by one cent per share or less. MONTH3 is an indicator variable equal to one if the month is the third month of a fiscal quarter. QTR4 is an indicator variable equal to one if the quarter is the fourth fiscal quarter. INCOME is income before extraordinary items deflated by assets at the beginning of the year; BM is the book-to-market ratio. SIZE is the natural logarithm of market capitalization. P-values in parentheses are based on robust firm-clustered standard errors (e.g., Rogers [1993], Petersen [2005]). ***, **, and * indicate significance at 1\%, $5 \%$, and $10 \%$ levels.

(1)

INTERCEPT

MBE

MONTH3

MBE*MONTH3

QTR4

MBE*QTR4

SIZE

INCOME

BM

Observations

Adjusted R-squared
(2)

(3)

(4)

$\begin{array}{cccc}0.0003 & 0.0015 & 0.0015 & 0.0011 \\ (0.000)^{* * *} & (0.000)^{* * *} & (0.000)^{* * *} & (0.000)^{* * *} \\ -0.0001 & -0.0001 & -0.0001 & 0.0000 \\ (0.065)^{*} & (0.075)^{*} & (0.014)^{* *} & (0.642)\end{array}$

$-0.0001$

(0.900)

0.0001

$(0.061)^{*}$

0.0001

$(0.009)^{* * *}$

$-0.0002$

$(0.001)^{* * *}$

-0.0001
$(0.000)^{* * *}$

$-0.0001$

$(0.000)^{* * *}$

$-0.0001$

$(0.000)^{* * *}$

$$
-0.0019
$$

$-0.0019$

(0.492)

$-0.0001$

(0.885)

(0.491)

$-0.0005$

$(0.003)^{* * *}$

$(0.003)^{* * *}$

$-0.0003$

$(0.001)^{* * *}$

18,503

18,098

18,098

18,098

0.0001

0.0047

0.0048

0.0099 
Table 7. Tests of real earnings management based on monthly advertising expenditures. The table reports estimation results of models whose dependent variable is monthly abnormal advertising expenditures. These are calculated based on the residuals from firm-specific time-series models estimated up to 60 months (an average of 30 months). The analysis is conducted on a limited number of observations that are closest to the area of zero earnings. Specifically, we use observations whose earnings before extraordinary items deflated by total assets is between -0.0075 and 0.00625 . SUSPECT is an indicator variable equal to one if quarterly income before extraordinary items deflated by total assets is above 0 and less than $0.0125 \%$. MONTH3 is an indicator variable equal to one if the month is the third month of a fiscal quarter. QTR4 is an indicator variable equal to one if the quarter is the fourth fiscal quarter. INCOME is income before extraordinary items deflated by assets at the beginning of the year; BM is the book-tomarket ratio. SIZE is the natural logarithm of market capitalization. P-values in parentheses are based on robust firm-clustered standard errors (e.g., Rogers [1993], Petersen [2005]). ${ }^{* * *},{ }^{* *}$, and $*$ signify significance at $1 \%, 5 \%$, and $10 \%$ levels.

\begin{tabular}{lcc} 
& $\mathbf{X}=$ & $\mathbf{X}=$ \\
& LNAGE & MARGIN \\
\hline INTERCEPT & 0.0019 & 0.0013 \\
& $(0.000)^{* * *}$ & $(0.001)^{* * *}$ \\
SUSPECT & -0.0014 & -0.0004 \\
& $(0.002)^{* * *}$ & $(0.006)^{* * *}$ \\
MONTH3 & 0.0001 & 0.0001 \\
& $(0.022)^{* * *}$ & $(0.018)^{* * *}$ \\
SUSPECT ${ }^{*}$ MONTH3 & -0.0002 & -0.0001 \\
& $(0.700)$ & $(0.296)$ \\
X & -0.0003 & -0.0001 \\
SUSPECT ${ }^{*}$ X & $(0.001)^{* * *}$ & $(0.427)$ \\
& & -0.0068 \\
SUSPECT ${ }^{*} \mathbf{X}^{*}$ MONTH3 & 0.0004 & $(0.641)$ \\
SIZE & $(0.010)^{* * *}$ & 0.0258 \\
Observations & 0.0001 & $(0.023)^{* * *}$ \\
INCOME & $(0.733)$ & -0.0001 \\
& -0.0001 & $(0.011)^{* *}$ \\
& $(0.060)^{* *}$ & -0.0066 \\
& -0.0073 & $(0.124)$ \\
& $(0.118)$ & -0.0001 \\
& -0.0001 & $(0.291)$ \\
& $(0.349)$ & 30,124 \\
& 29,561 & 0.0054 \\
\hline
\end{tabular}


Table 8. Tests of real earnings management based on monthly advertising expenditures following SOX. The table reports estimation results of models whose dependent variable is monthly abnormal advertising expenditures. These are calculated based on the residuals from firm-specific time-series models estimated up to 60 months (an average of 30 months). SUSPECT is an indicator variable equal to one if quarterly income before extraordinary items deflated by total assets is above 0 and less than $0.0125 \%$. SOX is an indicator variable taking the value of one if the observation is in 2003 and onward and 0 otherwise. INCOME is income before extraordinary items deflated by assets at the beginning of the year; BM is the book-to-market ratio. SIZE is the natural logarithm of market capitalization. P-values in parentheses are based on robust firm-clustered standard errors (e.g., Rogers [1993], Petersen [2005]). ***, **, and * signify significance at $1 \%, 5 \%$, and $10 \%$ levels.

\begin{tabular}{lc}
\hline INTERCEPT & 0.0014 \\
SUSPECT & $(0.001)^{* * *}$ \\
& -0.0004 \\
SOX & $(0.029)^{* *}$ \\
& -0.0001 \\
SOX*SUSPECT & $(0.539)$ \\
& -0.0000 \\
SIZE & $(0.890)$ \\
& -0.0001 \\
INCOME & $(0.010)^{* * *}$ \\
& -0.0071 \\
BM & $(0.124)$ \\
& -0.0001 \\
Observations & $(0.293)$ \\
Adjusted R-squared & \\
\hline
\end{tabular}

